\title{
PSEUDO-CLEMENTINE WRITINGS AS EVIDENCE OF FRIENDSHIP, CHRISTIAN COMMUNITY, AND POLEMICS IN THE EARLY CHURCH ${ }^{1}$
}

\author{
J I Ř I H O B L Í K
}

\section{ABSTRACT}

This study focuses on the Pseudo-Clementine writings as examples of Jewish-Christian literature between the second and fourth centuries CE. In view of their mutual antagonism and friendship, it interprets them as an attempt at orthodoxy, an instance of the line which led from Paul's mission to the Nicaean Council. On the one hand, the Pseudo-Clementines introduce peculiar rationalist Christology, while at the same time opposing both Gnosticism and paganism, as well as coming to terms with other early Christian schools. They also use the image of family to represent the Christian community connected by love, in which relationships acquire a new quality as compared to friendship.

Keywords:

Pseudo-Clementines; Friendship; Love; Church; Opponents; Jewish Christianity; Christology

DOI: $10.14712 / 23363398.2020 .56$

$\mathrm{T}$ he history of early Christianity is marked by the polarity of affiliation and controversy. The Christian movement at that time was still at an early stage of structure forming and the Pseudo-Clementines, representing Jewish Christianity as one of its parts, are distinguished by their firm stand against its opponents, especially Gentiles and Gnostics. Their strong polemical interest goes hand in hand with

1 This study is a result of research funded by the Czech Science Foundation within the GA ČR 19-02741S project, 'The Transmission and Transformation of Ideas in Hellenism, Early Judaism, and Early Christianity'. 
the fictitious story of the future Bishop Clement of Rome, which in turn aimed to show his friendly relationship with the Apostle Peter in his role as a bishop and the reunion of Clement's family as the image of the Church and community of love. As far as possible, our study will attempt to explain some specific features of the Pseudo-Clementines regarding both these objectives, the former of which is mainly embodied in speeches and dialogues, whereas the latter in narration. We would like to suggest that the enmity Clement and Peter experienced contrasts with their personal friendship, and that this friendship corresponds to some ancient notions of friendship, but also that it is only a stage of a path leading to a more deeply based (as relating to Christ) and more fundamentally focused (in terms of salvation) Christian community.

From the early Christian collection of Pseudo-Clementines, two most important writings stand out: first, the novel óplíal (Hom.; Homilies), supplemented at the beginning by Peter's Letter to James, James' Reply (Cont.), and Clement's Letter to James, and secondly, Recognitiones (Rec.; Recognitions, an originally Greek version of the previous letter, surviving only in Latin), the Second Letter of Clement, and two

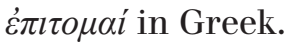

The story of the Homilies and Recognitions takes place in the first century, in the time of Clement and Peter, but their attribution to Clement as the historical Bishop of Rome (cf. Irenaeus, Adv. haer. 3.3.3 [SC 211:36.51]) can only be pseudo-epigraphic. Jewish Christianity, as portrayed in the Pseudo-Clementines, had already diverted from its original embrace of the partisans of the synagogue professing Christ.

In any case, the material of the Pseudo-Clementines is markedly pre-Nicaean. Although some scholars have identified Arian theology in the Homilies, ${ }^{2}$ Oscar Cullmann attributed the purportedly Arian passages to Jewish Christians. ${ }^{3}$ On the other hand, the Homilies were probably written not long before the outbreak of the Arian dispute, i.e. $318 \mathrm{CE} .{ }^{4}$ As a translation, the Recognitions is already post-Nicae-

\footnotetext{
Cf. Charles Bigg, Clementine Homilies (Oxford: Clarendon, 1890), 167.191-192.

Cf. Oscar Cullmann, Le problème littéraire et historique du roman pseudo-clémentin, étude sur le rapport entre le gnosticisme et le judéo-christianisme (Paris: Librairie Félix Alcan, 1930), 161.

4 Annette Yoshiko Reed puts Homiliai in 300-320, cf. 'Heresiology and the (Jewish-) Christian Novel: Narrativized Polemics in the Pseudo-Clementine Homilies,' in Heresy and Identity in Late Antiquity, ed. Eduard Iricinschi, and Holger M. Zellentin (Tübingen: Mohr, 2008), 273-298, 273.
} 
an. It was accomplished in the fifth century CE by Tyrannius Rufinus (ca 345-411/412), who is probably also responsible for some of the adjustments motivated by conformity with anti-Arianism. ${ }^{5}$

\section{Narrative, Friendship, and Opponents}

The narrative forms only a minor part of the two main Pseudo-Clementine writings, the majority of it consisting of extensive theological speeches. Rather than being written at one instance as a whole, it was inspired by an older narration about two main opponents, Peter and Simon (written after $190 \mathrm{CE}){ }^{6}$

It is particularly important in combining speeches and pictures of rigmaroles and crises of life, culminating in the happy reunion of Clement's family. It also evidences the significance of church authorities, specifically the authority of Bishop Peter, who is portrayed as both a charismatic personality and a pilgrim. He is both Clement's spiritual teacher and personal friend, i.e. he cares for him and wants the best for him (Peter calls Clement a friend in Hom. I 16; II 36; Rec. I 21.22).

This image of friendship corresponds materially to Aristotle's concept of perfect friendship, which

is that between the good, and those who resemble each other in virtue. For these friends wish each alike the other's good in respect of their goodness, and they are good in themselves; but it is those who wish the good of their friends for their friends' sake who are friends in the fullest sense since they love each other for themselves and not accidentally (Eth. Nic. 1156b6).

By analogy, Peter's friendship to Clement ensues from the former's character and the nature of his own mission.

The introductory passage describes Clement's education and conversion (Hom. I 1-6; Rec. I 1-3). We learn that Clement was intrigued by serious matters from his youth (which is an obvious literary tropus): whether the world was created, what was before creation, what will be after the destruction of the world, and whether there is individual

5 Cf. F. Stanley Jones. An Ancient Jewish Christian Source on the History of Christianity: Pseudo-Clementine 'Recognitions' 1.27-71 (Atlanta, Ga: Scholar Press 1995), 42-44.

6 Cf. Jürgen Wehnert. Pseudoklementinische Homilien: Einführung und Übersetzung (Göttingen: Vandenhoeck \& Ruprecht, 2010), 32. 
existence after death. ${ }^{7}$ However, he was not satisfied with the answers provided by contemporary philosophy; in its place, he found mere sophistry (Hom. I 3.1-4; Rec. I 3.1,3; cf. e.g. Phaedo 89d $-90 \mathrm{c}_{7}$ ). ${ }^{8}$ Having been told about a prophet of the East he traveled to Alexandria, where he took the advice of Barnabas, a Christian orator, and accompanied him to Caesarea Maritima.

In Caesarea, Clement met the Apostle Peter (Hom. I 15) who had arrived shortly before him to confront his opponent, Simon Magus (Hom. I 15), a celebrity of his time already mentioned in the Book of Acts (8:9). He seems to have been a Gnostic who considered himself

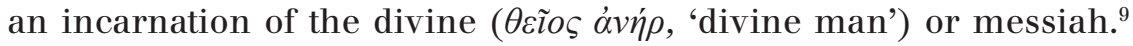
Peter's conflict with this arch-heretic defines a certain line of thought and action culminating at the end of the story in Simon's defeat and escape (Hom. XX 13).

After the moment Clement and Peter meet, the story of Clement's journey blends with the second storyline, namely Peter's journey from Caesarea along the Syrian coast to Antioch on the Orontes. During this journey, Clement meets all his lost family members one by one, thus coming to recognition (gr. $\dot{\alpha} v \alpha \gamma v \omega \rho \imath \sigma \mu o ́ \varsigma$, lat. recognitio). The story of recognition is actually a sort of narrative Platonism, presenting a polemic alternative to Gnosticism and, most importantly, advocating personal relationship to Christ - 'the Prophet of the truth' (s.b.). The

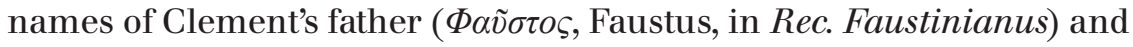

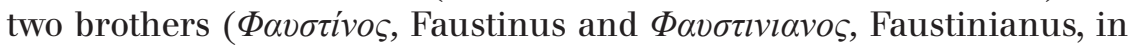
Rec. Faustinus and Faustus) are reminiscent of the Latin expression faustus (happy, the one who brings good luck), thus anticipating the fate of their bearers. This is to show that happiness or good luck is conferred neither by Fortune (upon which Faustus had previously relied) nor by a timetable encoded in the stars, but rather by the fulfilment of the true goal of life, pursued by the Christian community. Thus true knowledge is a road to happiness. The conversion of family members is not only a turning point in their personal conviction but also the discovery of a new perspective in life, wherein the renewal of family ties means a surprising fulfilment of an almost forsaken hope, but also

7 Cf. Nicole Kelley, Knowledge and Religious Authority in the Pseudo-Clementines: Situating the Recognitions in Fourth-century Syria (Tübingen: Mohr, 2006), 8 note 27.

See Kelley, Knowledge, 46-49.

9 Cf. Kurt Rudolf, Gnosis: The Nature and History of Gnosticism, trans. McLachlan Wilson, reprint 2th ed. (Edinburgh: T \& T Clark, 1998), 294-298. 
the defence of traditional family structures and benefit of the children. This requires moral integrity; however, the defence of the family is not intended to be just a moral example. The image of a good family is also an ideal image of the Christian community and mutual affectionate relationships between its members beyond the notion of friendship.

The Homilies use the term $\varphi \imath \lambda i \alpha$ (cf. lat. amicitia in the Recognitions), 'friendship', in its usual sense of interpersonal relations and only exceptionally as a theoretical subject, e.g. in Hom. XII 25.26 on the superiority of philanthropy ( $\varphi \imath \lambda \alpha \nu \theta \rho \omega \pi i \alpha$, universal love) over friendship (reciprocity and mutual benefit). The etymological affinity of these two terms calls for comparison. However, the latter is one of the major themes of the Pseudo-Clementines and overlaps to a large extent with the notion of love. One of the constituents ( $\mu \varepsilon \dot{\rho} \rho \varsigma)$ of philanthropy is love ( $\dot{\alpha} \gamma \alpha \dot{\alpha} \pi \eta$ in XII 32) $)^{10}$ for everyone; it is manifested by doing well even to enemies. It is evident that the traditional Greek notion of philanthropy is conceived in the light of the $\dot{\alpha} \gamma \alpha \dot{\alpha} \eta \eta$, 'love' in the NT sense. Besides, the subject matter here is only certain specific forms of love, not the concept of love in its entirety (love that determines and fulfils human life, cf. God's love for humans, I 39, love for God, III 8, but also love for truth,

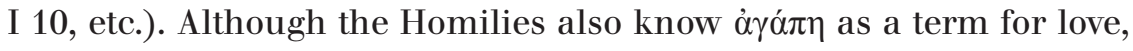
they mention the noun only seven times, while the verb $\alpha \gamma \alpha \pi \alpha ́ \omega$ occurs exactly eight times as more often. The verb refers, not surprisingly, to

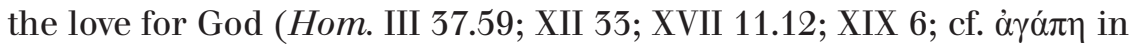
XVII 12), for one's neighbours as discussed particularly in the twelfth homily (Hom. XII 2.26.32.33, cf. III 69) and even for one's enemies (Hom. III 19; XII 32). In this, the Homilies only follow Christian usage. It is interesting, however, that the verb is also used for relationships in Clement's family (XIII 5.10; XIV 7.9.10; XVIII 22; XX 20), which supports our assumption that this family embodies a Christian community of love.

The relationship of love and friendship does not mean the same thing. Friendship is the relationship of God to a person who does his will (Hom. VIII 10; Rec. I 26; III 71; V 26.28.29; cf. Wis 7:27). In this case, it is rather an expression for a favourable relationship: God becomes a friend to humans, or even makes them friends 'for his Son' (Rec. IX 4; cf. also IX 9). Christ also has merit for God's friendship with people (cf. Hom. VIII 10; Rec. IV 9; IX 3) so that friendship becomes an

10 The other of the two constituents is compassion. 
interesting concept in terms of Christology (cf. the apostles as 'friends' of the Lord in Hom. III 71 and John 15:15). According to the Pseudo-Clementines, Peter's preaching also helps God's friendship if its content is imprinted in the listeners' memory (Rec. I 26). Even Abraham was honoured by him (Hom. XVIII 13; Aphrahat in Hom. XVII 3). On the level of interpersonal relationships (cf. e.g. Hom. II 1; IV 1; XIII 8; XIV 11; XV 2; XX 11.14.15.21; Rec. VI 15; VII 4; X 52.55.58.62.63) it is true that a friend is favoured, and this title is also his appreciation (in the Recognitions, sometimes the term familiaris 'acquaintance, familiar' occurs as parallel to 'friend', e.g. VII 23). The aspect of favour can then be recognized in a distorted form in the 'friends of demons' (Rec. IX 33; 'a friend of the prince of this world, and of all demons' in VI 9), in Simon's friends (Hom. II 18.20 .28; VII 3.11; XVI 1; XVIII 23; XIX 25; Rec. $X$ 68), in his pretence of friendship (Rec. II 8) or in the false friendship of yet another enemy, Apion (Hom. IV 8; V 2). Thus friendship is not an abstract value, but it also depends on who the friend is. In comparison with all these mentions of friendship, however, the friendship between Clement and Peter, which is constitutive of the story and thus deserves special attention, seems to be the most significant.

The concept of friendship in the Pseudo-Clementines, it may be asserted, is better illustrated by the narrative than by theory: although the relationship between Peter and Clement epitomizes friendship, the main thing is what this relationship leads to, namely the superiority of Christian love over friendship. This friendly relationship between the teacher and the pupil is also closely related to the conflict of their two opponents, from which Clemens himself is supposed to learn a lesson.

Although this is not obvious from our own considerations, the proper hero of the story is Simon Peter, who is invariably portrayed as a representative and advocate of pure and simple Christianity - as contrasted with his opponent, enemy, fraudster and heretic Simon Magus. The latter character unifies several polemical objectives. This synthesis is evident in the speech of Peter's companion Akylas when they meet Clement in Hom. II 22. The character of Simon displays the features of the historical character of Simon Magus in aspiring to greater power than God's and thinking himself to be the Christ. He was also 'opposed to Jerusalem', preferring Mount Gerizim over it as Samaritans did, as he actually came from Samaria (his Samaritan origin is confirmed e.g. by Justin Martyr, 1 Apol. 26 [PG 6, 368A]; for the anti-Samaritan polemics cf. Rec. I 54.4-5, I 57.1). He is also reminiscent of Marcion who denied 
the Creator as the supreme God, placing beside him God the Lawgiver (cf. also III 2; V 2; XVI 1-21). In that, he embodies heresy as a contrasting figure in relation to Peter and as his opponent (Hom. XVI 21), Peter himself represents the Jewish-Christian form of orthodoxy.

This distinction applies in a confusing situation of struggle in which distinction must be made between friends and enemies, as is clear from what Peter says about Simon:

... if he were known, he would not be believed; but now, not being known, he is improperly believed; and though his deeds are those of a hater, he is loved; and though an enemy, he is received as a friend; and though he be death, he is desired as a savior; and though fire, he is esteemed as light; and though a deceiver, he is believed as a speaker of truth (Hom. II 18).

\section{The Pseudo-Clementines as evidence of the differentiation of Jewish Christianity and opposition to Paulinism}

Our question of friendly relationships and coming to terms with one's opponents as presented in the Pseudo-Clementines is part of the Judeo-Christian frame of mind, as it historically developed in its variegated forms. Unsurprisingly, this type of Christianity was at home, mainly in Syria. This geographic area is suggested both by the scene of the story and the above-mentioned testimony by Eusebius, but also by

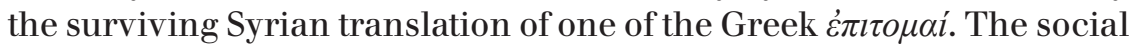
base was represented by a not very large but not negligible circle of adherents with their own independent literary tradition. ${ }^{11}$

The Pseudo-Clementines incorporate allusions to various Christian writings, ${ }^{12}$ although a direct dependence on early Christian movements (e.g. Elcesaites ${ }^{13}$ and Ebionites) ${ }^{14}$ is debatable. The Elcesaites were a Jewish-Christian movement with strong apocalyptic features, tracing its roots to a certain prophetic preacher called Elchasai. It was

11 See also Walter Bauer and Georg Strecker, Rechtgläubigkeit und Ketzerei im ältesten Christentum, 2th ed. (Tübingen: Mohr, 1964), 183.

12 Cf. Wehnert, Homilien, 36.

13 Cf. Gerhard Uhlhorn, Die Homilien und Recognitionen des Clemens Romanus nach ihrem Ursprung und Inhalt dargestellt (Göttingen: Dieterich, 1854), 399.401.

14 Cf. Adolph Schliemann, Die Clementinen nebst den verwandten Schriften und des Ebionitismus, ein Beitrag zur Kirchen- und Dogmengeschichte der ersten Jahrhunderte (Hamburg: Perthes, 1844), 201. 
established at the turn of the first and second centuries in Transjordan and later became widespread in Syria..$^{15}$ According to Epiphanius of Salamina (ca 315 to 403), the Ebionites were influenced by the Elcesaites, were neither Jews nor Christians, and accepted three writings,

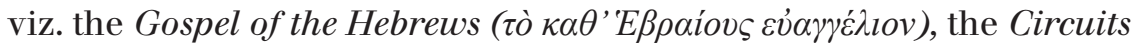

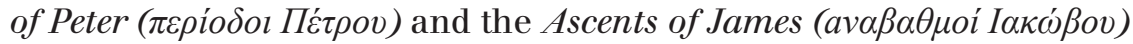
(Panarion 29.7.5 [GCS 25:330]). The Gospel of the Hebrews was said to be a broken and falsified gospel. According to it, Jesus was a man naturally born, who was entered into by Christ in the form of a dove and who refused to eat meat (Panarion 30.13; 14; 22 [GCS 25:350.351.263]). The Circuits of Peter allegedly spoke about the Ebionite teaching of Christ's birth as a human and his being created as one of the Archangels, designed to be their ruler, refusing to eat meat and rejecting sacrifices (Hom. XXX 15.1-4; 16.1-5). As compared to these Christological speculations, the Pseudo-Clementines are much more sober, as can be seen especially in their Christology. ${ }^{16}$ The Ascents of James allegedly advocated the Jerusalem form of Judeo-Christianity, anti-Paulinian in character (Hom. XXX 16.6-9; cf. Rec. I 27-71) but apparently of Jewish origin. ${ }^{17}$

The connection between the Pseudo-Clementines and the Jewish Christianity is materially attested by their mutual features, viz. restraint in identifying Jesus with God, high valuation of the Law, and limited meat consumption (cf. Hom. VII 8). However, circumcision was no longer practiced - with the exception of native Jews, according to Cont. 1,1. ${ }^{18}$ Another notable mark of their Jewish-Christian origin is the evaluation of Peter and James, 'the Brother of the Lord'. These two were closer to the Jewish Christians than the 'apostle of the Gentiles', Paul of Tarsus, who is not even mentioned by name and actually becomes an implicit object of criticism under the thin disguise of Simon Magus. This

15 Cf. Hans-Joachim Schoeps, Theologie und Geschichte des Judenchristentums (Tübingen: Mohr, 1949), 327.

16 Parallels are also sought for in their relation to the Samaritans, and their cosmology is reminiscent of the already mentioned movement of the Bardaisanites (turn of the second and third centuries) of Syrian Gnostic origin and yet not unrelated to Christianity. Cf. Bernhard Rehn, 'Bardesanes in den Pseudoclementinen,' Philologus 93, no. 1-2 (December 1938): 218-247.

17 Cf. Christfried Böttrich and Sabine Fahl, Leiter Jakobs (Gütesloh: Gütersloher Verlagshaus, 2015), 79.

18 Cf. Gerd Lüdemann, Paulus, der Heidenapostel: Antipaulinismus im frühen Christentum, II. Antipaulinismus im frühen Christentum, 2th ed. (Göttingen: Vandenhoeck \& Ruprecht, 1990), 244.256. 
is particularly clear in the polemics with Simon in Hom. XVII 13-20 (cf. Gal 1:11-12), where Peter casts doubts on visions and dreams as external means of revelation as it is not clear where they come from. Thus he indirectly questions the apostolic legitimacy of Paul, ${ }^{19}$ who unlike Peter was not a direct disciple of Jesus (cf. Rec. II 55). Rec. II 54 apparently alludes to Paul when Peter chastises Simon for bending the Law to suit his own agenda.

The alleged anti-Paulinian character of the Pseudo-Clementines is still a hotly debated issue, ${ }^{20}$ and we prefer to withhold our judgment in this respect. From the Christology and soteriology of the Pseudo-Clementines we can infer their distinctiveness of thought as compared to Paul's theory of vicarious death, bringing about reconciliation between God and humans (cf. Rom 3:25; 2Cor 5:18-20, etc.), although the vicariousness of Christ's suffering is not directly denied. Rather, the Pseudo-Clementines disagree with Paul's sola fide accent, emphasizing the need of good conduct for salvation..$^{21}$ Nevertheless, they claim that 'human love for God'

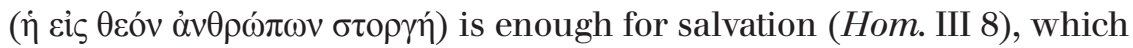
does not need to be opposed to the previous principle, no more than a mere 'justification by works' needs to be read into them. After all, they seem to be dealing mainly with Gnosticism and Marcionism. Although undoubtedly opposed to Paul, the Pseudo-Clementines only hint at some of his peculiar features and thought patterns in painting a negative picture of Simon. Moreover, it is sometimes rightfully pointed out that the actual subject of controversy is Marcion, or Marcion's interpretation of Paul..$^{22}$ In this context, it should also be noted that the theme of friendship plays a minimal role in Paul (there is no instance of the noun $\varphi 1 \lambda i \alpha$ in his letters and the verb $\varphi \imath \lambda \varepsilon ́ \omega$ occurs only in 1Cor 16:22).

As we can see, the Pseudo-Clementines deviate from Judaism and also from other Jewish-Christian movements, but they are not in opposition to either: Simon is perceived as a more serious adversary.

19 Cf. Lüdemann, Paulus, 251.

20 Cf. F. Stanley Jones, 'The Pseudo-Clementines: A History of Research, Part I and II,' in Pseudoclementina Elchasaiticaque inter Judeochristiana: Collected Studies (Leuven: Peeters, 2012), 81-113. For evidence of anti-Paulinism in the Pseudo-Clementines, cf. Lüdemann, Paulus, 228-257.

21 Cf. Marcel Simon Strasbourg, 'On Some Aspects of Early Christian Soteriology' in Man and His Salvation: Studies in Memory of S. G. F. Brandon, ed. Eric J. Sharpe, and John R. Hinnels (Manchester: Manchester University Press, 1973), 263-280.

22 Cf. Stanley Jones, 'The Pseudo-Clementines,' 152-171. 


\section{The Christology of the Pseudo-Clementines}

As we have seen, the story of the Pseudo-Clementines conceives friendship as the initial form of an interpersonal relationship that connects people for the sake of a good goal, but which is ultimately transcended by the bond of Christian love that reflects the path of salvation. In our view, this is rooted in a specific Christology.

Jesus is portrayed as a prophet par excellence. He is called 'our Lord

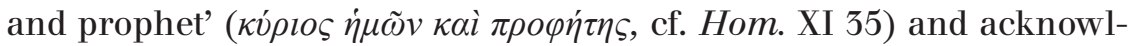
edged as a 'prophet of the truth' ( $\dot{\delta} \tau \tilde{\eta} \varsigma \dot{\alpha} \eta \theta \varepsilon i \alpha \varsigma \pi \rho \circ \varphi \dot{\eta} \tau \eta \varsigma$, cf. e.g. Hom. I 20,$4 ;$ II 5,$3 ; 6,1 ; 9,1)$ or 'the true prophet' ( $\dot{\alpha} \lambda \eta \theta \dot{\eta} \varsigma \pi \rho \circ \varphi \dot{\eta} \tau \eta \varsigma$, cf. e.g. Hom. II 17,4; III 11,2; 13,2; lat. verus propheta e.g. in Rec. I 16,1.2.4; 17,2.4.6). Clemens himself was interested in the 'teaching of the proph-

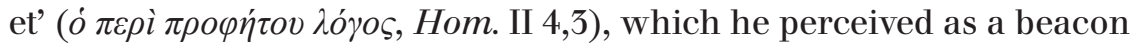
leading him through the jumble of teachings and in the direction that the prophet Jesus embodied. For the Pseudo-Clementines, the true prophet is the highest authority. He is justified in the fulfilment of his prophecies (cf. Hom. II 10,1; VIII 4,1 i.a.), and the Pseudo-Clementines claim that ancient prophecies have been fulfilled in Jesus' person (cf. Hom. III 53,3; Rec. I 40,4). Thus we can say that for the Pseudo-Clementines, Jesus is a messianic prophet. The Pseudo-Clementines share the idea of a messianic prophet with other Jewish religious movements (e.g. the Essenes), the only difference being that for the Pseudo-Clementines, the messiah had already come. ${ }^{23}$

Jesus as the true prophet is considered to be an interpreter of the Law (cf. Hom. III 51; XVIII 3; XX 9,2 and doctor legis, 'the teacher of the Law' in Rec. I 62,3), which is reflected not only in the emphasis on knowledge related to him (see below), but also in the title of Jesus as a teacher ( $\delta i \delta \dot{\alpha} \sigma \kappa \alpha \lambda o \varsigma$, cf. Rec. I 62,3), although he is also said to have come 'for the salvation ( $\sigma \omega \tau \eta \rho i \alpha)$ of the whole world' (Hom. XII 7,5; cf. XX 19,3; Rec. II 19,7; 28,3; 35,2; V 11,3; 61,3; VII 7,5). The concept

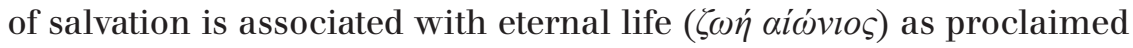
by Jesus (cf. e.g. Hom. I 7,2; II 5,2; III 18,3; Rec. I 7,3; 41,2; II 20,5; 22,5) who also receives 'the key of the kingdom, which is knowledge, which alone can open the gate of life, through which alone is the entrance to eternal life' (Hom. III 18,3).

23 Cf. Hans-Joachim Schoeps, Theologie und Geschichte des Judenchristentums, 87. For Jesus as a new Adam and new Moses, see also p. 98-99. 
Due to this distinctive Christology, Christianity differs from traditional Judaism in its notion of salvation. On the other hand, this difference is not particularly emphasized in Peter's sermon about the relationship between Jesus and Moses (cf. Hom. VIII 4-7; Rec. IV 4-6). Apart from this Jewish-Christian trait, the attitude voiced in Hom. VIII 7 is more explicitly Jewish-Christian: the Jews can be saved through their faith in Moses although they have never heard about Jesus, and similarly, Christians can be saved through their faith in Jesus, without ever having heard about Moses. Moses is viewed as a prophet ( $\dot{\delta} \pi \rho \varphi \eta^{\prime} \tau{ }^{\prime}$

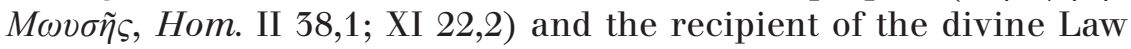
(Hom. III 47,1). ${ }^{24}$

However, the theme of salvation is not fully developed. While speaking about $\sigma \omega \tau \eta \rho i \alpha$ several times, the Homiliai never mention the related expressions $\sigma \tau \alpha v \rho o ̀ \varsigma$ (cross) and $\dot{\alpha} v \alpha \sigma \tau \alpha v \rho o ́ \omega$ (crucify), whereas $\dot{\alpha} v \alpha \dot{\sigma} \tau \alpha \sigma l \varsigma$ in the meaning of resurrection is mentioned only once (Hom. XVII 16,5). Jesus is titled as Christ and expected in his second coming (e.g. Hom. II 17,4-5). ${ }^{25}$ Yet the life 'in this world' seems to be more important, and Jesus is portrayed as a prophet and guide on this journey. This is made clear by the expression 'authoritative prophetic teaching' (Hom. II 15,5). In particular, the 'prophet' preaches the doctrine of the two ways (Hom. VII 7), as we know it e.g. from the Gospel of Matthew 7:13-14 and from the beginning of the early Christian treatise Didache (I-V, FC 1: 98-117).

It would be misleading to understand the Pseudo-Clementine Jesus as a mere guarantor of doctrine; as 'the true prophet', he actually transforms personal experience and perception. He alone is 'able to enlighten human souls so that they may see in their own eyes the path of eternal salvation' (Hom. I 19,1). He is indispensable because no principle is either true or false in itself, but only relative to the speaker (Hom. I 19,3-4). Without him, people have no access to the $\pi \iota \sigma \tau o$, 'reliable/ certain' (Hom. I 19,8) and he alone bestows the knowledge of immortality and other Christian doctrines, which is a prerequisite of their attainment (Hom. II 5,2). This can be seen as evidence of personal attachment to Christ as a mediator between people and God, an attachment constitutive of the Christian community.

\footnotetext{
${ }^{24}$ Chapter 47 justifies the thesis that the Law was not written by Moses, e.g. whether it was possible for Moses to write that Moses had died, cf. Hom. III 47,3.

25 For the Jewish-Christian understanding cf. Schoeps, Theologie, 78-82.
} 
In contrast to traditional Judaism, the Pseudo-Clementines insist that Jesus is the Son of God; on the other hand, this is exactly what he is: the Son of God as distinct from God (cf. e.g. Hom. I 7,2.7; 8,4; 9,2; XVI 15 and XVIII 13). If Jesus is God then only in so far as all people are (Hom. XVI 15,2; cf. 16,1-4). This restraint in identifying Jesus with God, open at the same time to overcoming the mutual distance between the two, can be viewed as one of the characteristic features of Jewish Christianity. It is also a testimony about the time before the First Council of Nicaea and the need to defend monotheism.

In the Pseudo-Clementines, monotheism is not only a concept of theology but also a touchstone of religious practice and lifestyle, a way to understand reality and the meaning of life. This can be clearly seen in the anti-Gentile metaphor (albeit not an original one) of monarchy and polyarchy. The superiority of monarchy over polyarchy rests in the fact that 'monarchy is capable of creating unity' (IX 2,3); unity does not fight against itself, whereas polyarchy has a tendency to mutual wars (IX 2,1). By analogy, God's unity corresponds to social unity on earth: the restored unity of Clement's family as an image of the unity of the Church. This unity in love is centred on Christ and focused on its fulfilment in salvation, which makes love, in the language of the Pseudo-Clementines, far superior to friendship.

Christology plays an important role in the Pseudo-Clementines as an interpretation tool of the distinguishing feature of Christianity (focus on Christ), which is to be of interest to members of the Christian community and which is itself the very source of their interest. The intention of these writings to educate the reader is rooted in Christology, so that in a controversy with their opponents and in the difficulties of their own lives, in which both friends and enemies play a role, they can succeed in reliance on the source of truth. The concept of friendship connects theology, Christology, and ethics of the Pseudo-Clementines with the Greek world, but its use is differentiated because it depends on whether the source of favour is God, or whether it is a real or even an apparent friend.

\section{Concluding remarks}

The ambiguity of the Pseudo-Clementines results from the fact that they do not represent a distinctive orthodoxy but rather a peculiar attempt at orthodoxy, leading to a distinctive soteriology which is both 
rational and interpersonal, e.g. in the dialogical relationship between friends and within the family as a communio christiana and in relation to Christ, who is the common point of reference by which the human view transcends to the source of truth, with its benefits for humans. The doctrine that also included this type of Christology was thus meant not only to be proclaimed but also practically applied in social relationships and differences - including both friends and opponents. At the same time, Peter and Clement were opponents of Gnosticism, Marcionism, and Paganism, yet their story involved much more than just a refutation of certain doctrines.

The Christology of the Pseudo-Clementines is therefore fairly rationalist. Jesus is the Savior mainly in that he communicates to people the path of salvation. The motif of the journey is markedly expressed in the pilgrimage of Peter and Clement, but also in the wandering and reunion of members of Clement's family, so his whole story involves the direction towards salvation that the united family is to embody and foreshadow. The concept of a rational path to salvation is important because the Savior is not only a salvific agent of an objective spiritual reality but also a counterpart of humans, whereas people are conscious and responsible recipients of salvation. Thus the rationalist interpersonal Christology is well suited to the image of the family as a communion of love, in which also philanthropy has its starting point.

Knowledge as a fundamental prerequisite of salvation is not a human exercise but a gift. The recognitio as the principle of Clement's story expresses the promise of salvation in the form of renewal and rehabilitation of humanity in its social dimension. This illustrates the attitude of the Pseudo-Clementines: in them, orthodoxy is not only a doctrine but also and foremost a lifestyle. Needless to say, the retrieval of what had been lost as an aspect of salvation is already a part of Jesus' teaching, his parable of the lost sheep ( $L$ 15:4-7). The role of inter-personality and social dimension in the process of salvation shows that the concept of 'friendly' relationships does not suffice to describe the existentially necessary aspects of fellow-humanity, threatened as they are by destruction and hopelessness beyond the human potential.

In light of this, the concept of friendship ought to be understood: in the Pseudo-Clementines, it is fundamentally related to the whole. The friendship between Clement and Peter is the starting point and a constitutive feature of the story, in which the image of friendship is surpassed by the community of love. The contrast with the adversaries, 
radically excluded from the community, thus appears to be even more pungent. On the other hand, in other relationships, the concept of friendship does not play such a strong, profiled, and distinctive role (e.g. Clement's relatives are mentioned as friends only occasionally and God's 'friendship' expresses only a partial view of God's relationship to humans). The friendship between Clement and Peter thus starts to work as a paradigm, showing that Christians need a trustworthy partner on their path of salvation, in the midst of a confused and conflicting world, to reach the saving knowledge from the 'prophet of truth'. Thus, the restoration of the family and the settlement of hostile doctrines is an image of salvation and the presence of salvation in this world.

Center for Classical Studies at the Institute of Philosophy, CAS Na Florenci 3 11000 Praha 1 Czech Republic E-mail: hoblik@ics.cas.cz 